\title{
Pengaruh Suhu Dan Waktu Tinggal Terhadap Kecenderungan Menguning Pada Proses Produksi Alumunium Fasad
}

\author{
Sukram $^{(1)}$ Sutikno ${ }^{(2)}$ \\ ${ }^{(1)}$ Program Studi Teknik Mesin, Sekolah Tinggi Teknologi Gempol \\ Email : sukram.pati@gmail.com ${ }^{(1)}$
}

\begin{abstract}
Abstrak
Pengecatan menggunakan cat bubuk merupakan salah satu teknik perlindungan terhadap korosi yang berkembang secara pesat. Cat bubuk memiliki nilai estetika mendekati cat cair serta daya tahan dan utilisasi yang relative lebih baik dibanding cat cair. Proses pematangan cat bubuk yang hanya dilakukan dengan proses pemanasan pada suhu tertentu dan rentang waktu tertentu. Standard proses pematangan dikenal dengan kurva pematangan (curing map). Perbedaan suhu dan waktu terhadap rentang nilai standar menimbulkan resiko terjadinya perubahan warna khususnya pada warna putih (terang). Oleh sebab itu dilakukan penelitian untuk mengetahui pengaruh suhu dan waktu pemanasan terhadap kecenderungan menguning pada cat bubuk warna putih. Pengukuran warna dilakukan dengan menggunakan colorimeter dalam satuan CIE Lab. Nilai b pada CIE lab menunjukan kecenderungan warna kekuningan atau kebiruan. Suhu dan waktu pemanasan merupakan variabel penelitian yang faktornya ditentukan $5^{\circ} \mathrm{C}$ dan 5 menit diluar kurva pematangan.
\end{abstract}

Kata Kunci:Cat bubuk, pematangan, suhu, warna

\begin{abstract}
Painting using paint powder is one of the techniques of protection against corrosion are evolving rapidly. Powder paints have aesthetic value approaching liquid paint as well as durability and relative utilization is better than liquid paint. The process of maturation of the paint powder that is only done with the process of warming at a certain temperature and a certain span of time. Standard maturation process known as maturation curve (curing folder). The difference in temperature and time against standard value ranges of risk occurrence of color change especially in white color (light). Therefore, do the research to find out the influence of temperature and time of warming up against the tendency of yellowing in white powder paint. Colour measurement is performed using a colorimeter in units of CIE Lab. Value $b$ in CIE lab color trend show the yellowish or bluish. Temperature and time of warming up is the variable factor research determined 5 .
\end{abstract}

Keyword : paint powder, maturation, temperature, color.

\section{Pendahuluan}

Pertumbuhan aluminium extruder di Indonesia sangat pesat khususnya di Jawa Timur. Tingginya permintaan pasar untuk produk aluminium sebagai material fasad pengganti kayu memunculkan industri tersebut. Aluminium merupakan material utama pengganti kayu yang digunakan dalam industri mebel maupun bahan bangunan [1]. Aluminium memiliki keunggulan dalam hal tingkat kepresisian yang baik, penampilan yang artistik, mampu meminimalkan celah dan kemudahan proses fabrikasi [2],[3],[4],[5]. Pengecatan dan anodizing merupakan dua teknik pelapisan yang digunakan 
dalam produksi material fasad [3],[6],[7]. Pengecatan memiliki nilai estetika yang lebih tinggi yang ditandai dengan variasi warna dan tekstur yang lebih banyak dibanding anodizing.

Aplikasi pengecatan menggunakan cat bubuk (powder coating) berkembang pesat dalam beberapa decade terakhir. Cat bubuk memiliki keunggulan dalam hal minimnya tingkat polusi terhadap lingkungan sekitar dan dapat cat yang tidak menempel dapat digunakan kembali (recycle system) [8]. Aplikasi cat bubuk banyak digunakan untuk komponen kendaran bermotor atau mesin, aluminium extruder sebagai bahan untuk fasad [9],[10], serta berbagai keperluan rumah tangga. Kualitas hasil pengecatan cat bubuk belum memiliki standar nasional sehingga masih mengacu pada standar yang berlaku di Eropa (qualicoat) dan Amerika [11].

Kualitas hasil proses pengecatan dideteksi dari kekuatan dan tampilan. Faktor estetika atau keindahan terkait dengan tampilan lapisan cat yang memiliki karakter kualitas yang kritis (Ctritical to Quality/ (CTQ) Perbedaan warna $(\triangle E)$ dan kilap lapisan cat atau biasa disebut kilap (gloss). Proses Pematangan dan jenis cat sangat berpengaruh terhadap dua $C T Q$ tersebut. Warna putih merupakan warna yang sangat mudah mengalami peruabahan warna, apalagi jika memiliki tingkat kilap yang tinggi. Warna putih cenderung menjadi kekuningan jika proses pematangan tidak tepat atau bereaksi dengan udara hasil pembakaran tidak sempurna. Salah satu warna yang banyak digunakan di proses produksi pelapisan aluminium extruder adalah warna beigi pure white 01 ( $P W$-01). Karakter warna $P W-01$ adalah sensitif terhadap panas dan memiliki kilap sedang, sehingga berpotensi menguning dan terjadi penurunan kilap pada waktu proses pematangan [12],[13]. Kecenderunganmenguning pada cat bubuk dapat diukur dengan menggunakan colorimeter dalam satuan CIE Lab yang memiliki nilai spesifikasi maksimal 0,5. Pengukuran kilap menggunakan glossmeter dan memiliki spesifikasi $77 \pm 7$ untuk warna $P W-01$.

Proses pematangan dapat dilakukan dengan berbagai metode pemanasan [14]. Sumber panas dalam oven dapat diperoleh dari pemanas elektrik maupun pembakaran bahan bakar. Pemanasan elektrik dan pembakaran tidak langsung memiliki keunggulan dalam hal minimnya kontaminasi gas buang hasil pembakaran sehingga dapat mencegah terjadinya reaksi cat dengan gas buang [15]. Penggunaan pemanas listrik efektive untuk skala laboratorium atau produksi dalam jumlah kecil, sedangkan sistem pemasanan dengan sirkulasi gas panas efektif untuk produksi kontinyu dalam skala besar. Industri menengah dan kecil pada umumnya menggunakan oven dengan pembakaran langsung baik untuk sistem batch maupun kontinyu sehngga potensi terjadinya cat menguning lebih besar.

Penelitian tentang optimasi $\Delta E$ dan kilap dilakukan untuk mengurangi kegagalan proses pengecatan. Menurut [16] melakukan penelitian tentang optimasi kilap pada cat untuk marka jalan dengan faktor input formulasi dan pigmen pada 2006. Optimasi $\Delta \mathrm{E}$ dilakukan oleh [17] dengan faktor input formulasi. Penelitian tersebut menggunakan metode mixture karena terkait dengan faktor input formulasi Menurut [18] mengoptimasi $\Delta \mathrm{E}$ pada tinta percetakan dengan metode permukaan respon. Pada tahun 2016 [19], meneliti perubahan warna cat bubuk pada tunnel oven.

\section{Metode Penelitian}

Perancangan percobaan menggunakan Central Composite Design (CCD) yang terdiri dari tiga respon yang dipengaruhi oleh dua faktor. Respon dalam percobaan ini adalah $b, E$, dan kilap, sedangkan faktor meliputi suhu oven dan waktu proses [20],[21]. Penentuan level dari faktor mengacu pada waktu dan suhu pematangan standar yaitu $180^{\circ} \mathrm{C}$ selama 20 menit atau $200^{\circ} \mathrm{C}$ selama 10 menit. Level minimum dan maksimum ditentukan dengan memberikan penyimpangan $5^{\circ} \mathrm{C}$ untuk suhu dan 5 menit untuk waktu sehingga menghasilkan level faktor seperti table 1 dibawah ini. Penyimpangan dimaksudkan untuk mendeteksi adanya perubahan warna yang terjadi jika pematangan dilakukan diluar kurva standar pematangan.

Warna memiliki fungsi estetika dalam produksi pelapisan logam dengan senyawa organik. Warna yang terbentuk oleh lapisan cat sangat dipengaruhi oleh pigmen [22]. Warna tercipta dari interaksi antara cahaya dan pigmen yang terdapat dalam cat . Berbagai ragam warna yang dipancarkan cahaya akan diserap dan dipantulkan oleh pigmen sehingga terdeteksi oleh mata kita sebagai warna tertentu. Oleh sebab itu pengukuran warna paling sederhana adalah membandingkan secara visual contoh warna terhadap warna standar pada berbagai sudut pencahayaan. Teknik ini tidak mampu 
melakukan deteksi secara kuantitatif, sehingga perlu digunakan colorimeter digunakan untuk meningkatkan keakurasian pengukuran warna [23]. Pada kondisi aktual sangat sulit untuk menghasilkan warna yang benar-benar sama. Inspeksi secara visual tidak mampu mendeteksi sedikit perbedaan warna antar warna sejenis, sehingga dimungkinkan adanya toleransi $\Delta E$ pada colorimeter sebesar 0,5 [19], [16]:

Pengukuran warna pada prinsipnya mengukur $L, a$ dan $b$ dengan keterangan sebagai berikut

a. $L$ menyatakan tingkat kecerahan gelap $($ hitam $)=0$ dan cerah $($ putih $)=100)$.

b. $a$ menyatakan kecenderungan kemerahan hingga kehijauan ( merah $=+60$ dan hijau $=-60)$.

c. $b$ menunjukan tingkat kekuningan hingga kebiruan (kuning $=+60$ dan biru $=-60$ ). Perbedaan warna dinyatakan dalam E yang dihitung berdasarkan persamaan 2.1 berikut ini.

$$
\Delta E=\sqrt{(\Delta L)^{2}+(\Delta a)^{2}+(\Delta b)^{2}}
$$

Tiga satuan pengukuran $E$ yang sering digunakan adalah Hunter Lab, Commission Internationale de El Clairage (CIE) Lab dan Just Noticeable different (JND). Satu JND sama dengan sepertiga Hunter Lab, sama dengan setengah CIE Lab.

\section{Metode Permukaan Respon}

Metode statistika dan matematika sering digunakan untuk mempelajari hubungan antara beberapa faktor terhadap respon yang bersifat kuantitatif adalah metode permukaan respon (Response Surface Methodology). Penggunaan metode permukaan respon pada umumnya bertujuan untuk pemetaan respon, optimasi respon dan pemilihan kondisi operasi. Tahapan perancangan percobaan dengan metode permukaan respon menurut [24],[22] adalah mengindentifikasi masalah, menentukan respon, mengidentifikasi faktor dan menentukan level, perancangan percobaan, pelaksanakan percobaan, analisis statistik hasil percobaan, serta kesimpulan dan rekomendasi.

Data hasil percobaan dianalisis secara statistik untuk menyusun model regresi besreta pengujian modelnyal serta optimasi untuk menghasilkan seting terbaik dengan menggunakan fungsi desirability. Regresi orde dua yang bersifat lebih fleksibel dibanding regresi orde satu diharapkan mampu menyelasikan kasus yang tidak dapat diselesaikan dengan menggunakan orde satu [2]. Menurut [25] Persamaan regresi orde dua adalah sebagai berikut:

$$
y=\beta 0+\sum_{i=1}^{k} \beta_{i} x_{i}+\sum_{i=1}^{k} \beta_{i i} x_{i}^{2}+\sum_{i=1}^{k} \sum_{j=1}^{k} \beta_{i j} x_{i} x_{\mathrm{j}}+\varepsilon
$$

$y$ adalah respon atau variabel tidak bebas, $\beta_{0}$ adalah titik potong kurva (intersept), $\beta_{i}$ adalah koefisien regresi dari $x_{i}, \beta_{i i}$ adalah koefisien regresi dari $x_{i}^{2}, \beta_{i j}$ adalah koefisien regresi dari interaksi antara $x_{i}$ dan $x_{i j}, x_{i}$ adalah variabel bebas ke $i, \varepsilon$ adalah error. Pemodelan yang dihasilkan harus diuji dengan menggunakan uji kecukupan model, uji koefisien regresi, dan uji asumsi residual.

Persamaan regresi hasil permodelan digunakan sebagai dasar optimasi dengan menggunakan fungsi desirability. Fungsi tujuan dari optimasi dengan menggunakan fungsi desirability adalah memaksimalkan nilai desirability $(D)$ yang merupakan fungsi dari desirability individu (d) sesuai dengan persamaan 3 .

$$
D=\left(d_{\Delta E} \times d_{\Delta \Delta E} \times d_{\text {kilap }}\right)^{1 / 3}
$$

Respon $\Delta E$ dan $\triangle E E$ bersifat semakin kecil semakin baik sehingga $d_{i}$ dihitung dengan persamaan 4. Nilai $d_{i}=1$ jika $\hat{y}_{i}<T_{i}$ dan $d_{i}=0$ jika $\hat{y}_{i}>U_{i}$.

$$
d_{i}=\left(\frac{U_{i}-\hat{y}_{i}}{U_{i}-T_{i}}\right)^{\alpha i} \quad T_{i} \leq \hat{y}_{i} \leq U_{i}
$$


Kilap bersifat nominal terbaik sehingga perhitungan nilai $d_{i}$ menggunakan persamaan 5, 6, atau 7 .

$$
\begin{array}{ll}
d_{i}=\left(\frac{\hat{\mathrm{y}}_{i}-L_{i}}{T_{i}-L_{i}}\right)^{\alpha i} & L_{i} \leq \hat{y}_{i} \leq T_{i} \\
d_{i}=\left(\frac{U_{i}-\hat{\mathrm{y}}_{i}}{U_{i}-T_{i}}\right)^{\alpha i} & T_{i} \leq \hat{y}_{i} \leq U_{i} \\
d_{i}=0 & \hat{y}_{i}<L_{i} \text { atau } \hat{y}_{i}>U_{i}
\end{array}
$$

$L_{i}$ adalah batas bawah repon ke $i, T_{i}$ adalah nilai target respon ke $i, U_{i}$ adalah batas atas respon ke $i$ dan $\hat{y}_{i}$ adalah nilai taksiran respon ke $i$.

Tabel 1 Penentuan Label Faktor

\begin{tabular}{|c|c|c|c|}
\hline \multirow{2}{*}{ No } & \multirow{2}{*}{ Parameter Process } & \multicolumn{2}{|c|}{ Penentuan Level } \\
\cline { 3 - 4 } & & Bawah & Atas \\
\hline 1 & Suhu oven $\left(x_{1}\right)$ & $175^{\circ} \mathrm{C}$ & $205^{\circ} \mathrm{C}$ \\
\hline 2 & Waktu $\left(x_{2}\right)$ & 5 menit & 25 menit \\
\hline
\end{tabular}

Variabel bebas diubah dalam level pengkodean faktor untuk melakukan perhitungan matematis sesuai dengan persamaan 8 berikut ini [25]:

$$
x_{i}=\frac{x_{\text {real }}-\left(x_{\max }+x_{\min }\right) / 2}{\left.x_{\max }-x_{\min }\right) / 2}
$$

Percobaan dilakukan sebanyak 13 kali sesuai hasil perancangan percobaan dari program minitab 16 yang ditampilkan pada Tabel 2 .

Tabel 2 Rancangan Percobaan Central Composite Design

\begin{tabular}{|c|c|c|c|c|c|}
\hline Std.Order & Run Order & Pt.Type & Blocks & Suhu & Waktu \\
\hline 7 & 1 & -1 & 1 & 190 & 0.9 \\
\hline 6 & 2 & -1 & 1 & 211 & 15 \\
\hline 9 & 3 & 0 & 1 & 190 & 15 \\
\hline 13 & 4 & 0 & 1 & 190 & 15 \\
\hline 8 & 5 & -1 & 1 & 190 & 29.1 \\
\hline 3 & 6 & 1 & 1 & 175 & 25 \\
\hline 12 & 7 & 0 & 1 & 190 & 15 \\
\hline 4 & 8 & 1 & 1 & 205 & 25 \\
\hline 5 & 9 & -1 & 1 & 169 & 15 \\
\hline 10 & 10 & 0 & 1 & 190 & 15 \\
\hline 1 & 11 & 1 & 1 & 175 & 5 \\
\hline 2 & 12 & 1 & 1 & 205 & 5 \\
\hline 11 & 13 & 0 & 1 & 190 & 15 \\
\hline
\end{tabular}

\section{Hasil dan Pembahasan}

\section{Hasil Percobaan}

Data hasil percobaan pengecatan cat bubuk warna $P W-01$ pada plat aluminium dengan ketebalan $1.1 \mathrm{~mm}$ berupa nilai Lab. $\Delta E$ dihitung dengan menggunakan persamaan 8 . Hasil percobaan ditampilkan pada tabel 3 dibawah ini. 
Tabel 3 Data Hasil Percobaan

\begin{tabular}{|c|c|c|c|c|c|c|c|c|c|}
\hline $\begin{array}{c}\text { Std. } \\
\text { Order }\end{array}$ & $\begin{array}{c}\text { Run } \\
\text { Order }\end{array}$ & Pt. Type & Blocks & Suhu & Waktu & $\mathrm{L}$ & $a$ & $B$ & $\Delta E$ \\
\hline 7 & 1 & -1 & 1 & 190 & 0,9 & 93,51 & 1,07 & 9.17 & 1.11 \\
\hline 6 & 2 & -1 & 1 & 211 & 15,0 & 89,01 & 1,02 & 9.81 & 3.46 \\
\hline 9 & 3 & 0 & 1 & 190 & 15,0 & 92,61 & 1,06 & 9.3 & 0.21 \\
\hline 13 & 4 & 0 & 1 & 190 & 15,0 & 92,14 & 1,07 & 9.29 & 0.27 \\
\hline 8 & 5 & -1 & 1 & 190 & 29,1 & 91,52 & 1,05 & 9.66 & 0.93 \\
\hline 3 & 6 & 1 & 1 & 175 & 25,0 & 92,37 & 1,03 & 9.25 & 0.03 \\
\hline 12 & 7 & 0 & 1 & 190 & 15,0 & 92,65 & 1,04 & 9.28 & 0.25 \\
\hline 4 & 8 & 1 & 1 & 205 & 25,0 & 89,61 & 1,07 & 9.75 & 2.82 \\
\hline 5 & 9 & -1 & 1 & 169 & 15,0 & 92,7 & 1,03 & 9.27 & 0.3 \\
\hline 10 & 10 & 0 & 1 & 190 & 15,0 & 92,11 & 1,05 & 9.29 & 0.29 \\
\hline 1 & 11 & 1 & 1 & 175 & 5,0 & 92,86 & 1,05 & 9.21 & 0.46 \\
\hline 2 & 12 & 1 & 1 & 205 & 5,0 & 92,19 & 1,03 & 9.28 & 0.21 \\
\hline 11 & 13 & 0 & 1 & 190 & 15,0 & 92,68 & 1,06 & 9.17 & 0.29 \\
\hline
\end{tabular}

\section{Analisis Stasitik Hasil Percobaan}

Pengolahan data hasil percobaan menggunakan minitab 16 memperoleh hasil analisis variansi (ANAVA) untuk menguji koefisien regresi secara serentak yang ditampilkan pada Tabel 4. Pengujian secara serentak menunjukan bahwa persamaan regresi menunjukkan bahwa interaksi antar faktor tidak berpengaruh signifikan dalam pemodelan $\Delta E$ dan kilap. Secara umum keseluruhan komponen regresi, linier kuadratik dan interaksi erpengaruh secara statistik terhadap respon karena seluruh nilai $\mathrm{P}>0,05$. Nilai lack off fit pada model untuk $\Delta E$ memiliki nilai $\mathrm{P}<0,05$ sehingga hipotesis tidak terjadi lack off fit tidak dapat diterima. Dengan demikian permodelan untuk $\Delta E$ tidak memiliki kecukupan model.

Tabel 4 ANAVA

\begin{tabular}{|l|c|c|c|c|}
\hline Term & $P$ untuk L & $P$ untuk $a$ & $P$ untuk $b$ & $P$ untuk $E$ \\
\hline Regresi & 0,000 & 0,025 & 0,000 & 0,003 \\
\hline Linier & 0,001 & 0,007 & 0,017 & 0,011 \\
\hline Kuadratik & 0,001 & 0,007 & 0,012 & 0,013 \\
\hline Interaksi & 0,015 & 0,029 & 0,037 & 0,022 \\
\hline Lack off fit & 0,305 & 0,517 & 0,103 & 0,000 \\
\hline
\end{tabular}

Koefisien determinasi $R^{2}$ untuk respon $L$ yang ditampilkan pada Tabel 5 bernilai lebih dari 96,13\% sehingga 96,13\% gelap terangnya warna dipengaruhi oleh shu dan waktu pemanasan sesuai permodelan yang dihasilkan. Kecenderungan menguning 89,95\% dapat digambarkan oleh permodelan yang dihasilkab, sedangkan kecenderungan warna merah dan biru hanya mampu digambarkan sebanyak 71,49\%. Meskipun permodelan untuk $\Delta E$ memiliki lack off fit, akan tetapi kondisi yang mampu digambarkan oleh model sebanyak $84 \%$.

Tabel 5 Perkiraan Nilai Koefisien Regresi

\begin{tabular}{|c|c|c|c|c|c|c|c|c|}
\hline \multirow{2}{*}{ Keterangan } & $L$ & & $A$ & & $b$ & & $\Delta E$ & \\
\cline { 2 - 10 } & Koefisien & Nilai P & Koefisien & Nilai P & Koefisien & Nilai P & Koefisien & Nilai P \\
\hline Konstanta & $-279,222$ & 0,227 & $-11,064$ & 0,146 & 257,643 & 0,001 & 104,190 & 0,012 \\
\hline $\mathrm{X}_{1}$ & 12,988 & 0,000 & 0,0242 & 0,010 & $-0,1761$ & 0,012 & $-1,078$ & 0,013 \\
\hline
\end{tabular}


Tabel 5 Perkiraan Nilai Koefisien Regresi (Lanjutan)

\begin{tabular}{|c|c|c|c|c|c|c|c|c|}
\hline $\mathrm{X}_{2}$ & 0,5883 & 0,030 & $-0,0191$ & 0,028 & $-0,1211$ & 0,057 & $-0,941$ & 0,023 \\
\hline $\mathrm{X}_{1} \mathrm{X}_{1}$ & $-0,0035$ & 0,000 & $-0,0001$ & 0,007 & 0,0005 & 0,012 & 0,003 & 0,013 \\
\hline $\mathrm{X}_{2} \mathrm{X}_{2}$ & & & & & & & & \\
\hline $\mathrm{X}_{1} \mathrm{X}_{2}$ & $-0,0035$ & 0,015 & 0,0001 & 0,029 & 0,0007 & 0,037 & 0,005 & 0,020 \\
\hline $\mathrm{R}^{2}$ & \multicolumn{2}{|c|}{$96,13 \%$} & \multicolumn{2}{|c|}{$71,49 \%$} & \multicolumn{2}{|c|}{$89,95 \%$} & \multicolumn{2}{c|}{$84,00 \%$} \\
\hline
\end{tabular}

Perhitungan koefisien pada fungsi kuadratik untuk nilai interaksi antara waktu dan waktu memiliki nilai $\mathrm{P}>0,5$ sehingga secara statistik tidak berpengaruh signifikan terhadap model seperti yang ditampilkan padda table 5. Kondisi abnormal terjadi pada respon $b$ dimana faktor waktu memiliki nilai $P>0,5$ sehingga untuk tingkat keyakinan $95 \%$ maka secara statistic faktor waktu dianggap tidak berpengaruh secara signifikan. Tabel 6 menunjukan perhitungan jika faktor waktu dihilangkan (hanya faktor suhu yang berpengaruh signifikan) maka akan menghasilkan persamaan linier orde satu yang menghasilkan nilai $\mathrm{R}^{2} 37,97 \%$ dan Lack off fit 0,501 . Meskipun secara statistik kecukupan model terpenuhi akan tetapi hanya mampu menjelaskan 37,97\% dari kondisi sehingga lebih banyak dipengaruhi oleh faktor lain selain suhu. Oleh sebab itu faktor waktu tetap berpengaruh signifikan pada kecenderungan menguning untuk tingkat keyakinan $90 \%(\alpha=0,1)$ yang ditunjukan dengan nilai $\mathrm{P}$ untuk lack off fit sebesar 0,103 (P > 0,1). Permodelan yang dihasilkan lebih mampu menggambarkan hubungan antara faktor suhu dan waktu terhadap kecenderungan menguning.

Tabel 6 Perbandingan Permodelan Respon $b$

\begin{tabular}{|c|c|c|c|c|}
\hline \multirow{2}{*}{ Keterangan } & \multicolumn{2}{|c|}{$B$} & \multicolumn{2}{c|}{$b$ (dihilangkan waktu) } \\
\cline { 2 - 5 } & Koefisien & Nilai P & Koefisien & Nilai P \\
\hline Konstanta & 257,643 & 0,001 & 75,219 & 0,001 \\
\hline $\mathrm{X}_{1}$ & $-0,1761$ & 0,012 & 0,0111 & 0,012 \\
\hline $\mathrm{X}_{2}$ & $-0,1211$ & 0,057 & & \\
\hline $\mathrm{X}_{1} \mathrm{X}_{1}$ & 0,0005 & 0,012 & & \\
\hline $\mathrm{X}_{1} \mathrm{X}_{2}$ & 0,0007 & 0,037 & & \\
\hline $\mathrm{R}^{2}$ & $89,95 \%$ & \multicolumn{2}{c|}{$37,97 \%$} \\
\hline$P_{\text {Lack off fit }}$ & \multicolumn{3}{|c|}{0,103} & \multicolumn{3}{c|}{0,501} \\
\hline
\end{tabular}

\section{Penyusun Model Matematis}

Berdasarkan hasil analisis statistik di atas maka dapat disusun model matematis yang menunjukkan pengaruh suhu $\left(x_{1}\right)$, waktu $\left(x_{2}\right)$ terhadap $L\left(Y_{L}\right), \alpha\left(Y_{\alpha}\right)$, dan $b\left(Y_{b}\right)$ dalam persamaan berikut ini:

$$
\begin{aligned}
& Y_{L}=-27,9722+1,2988 x_{1}+0,5833 x_{2}-0,0035 x_{1}^{2}-0,0035 x_{1} x_{2} \\
& Y_{\alpha}=-1,1064+0,0242 x_{1}-1,091 x_{2}-0,0001 x_{1}^{2}+0,0001 x_{1} x_{2} \\
& Y_{b}=25,7463-1,761 x_{1}-0,1211 x_{2}+0,0005 x_{1}^{2}+0,0007 x_{1} x_{2}
\end{aligned}
$$




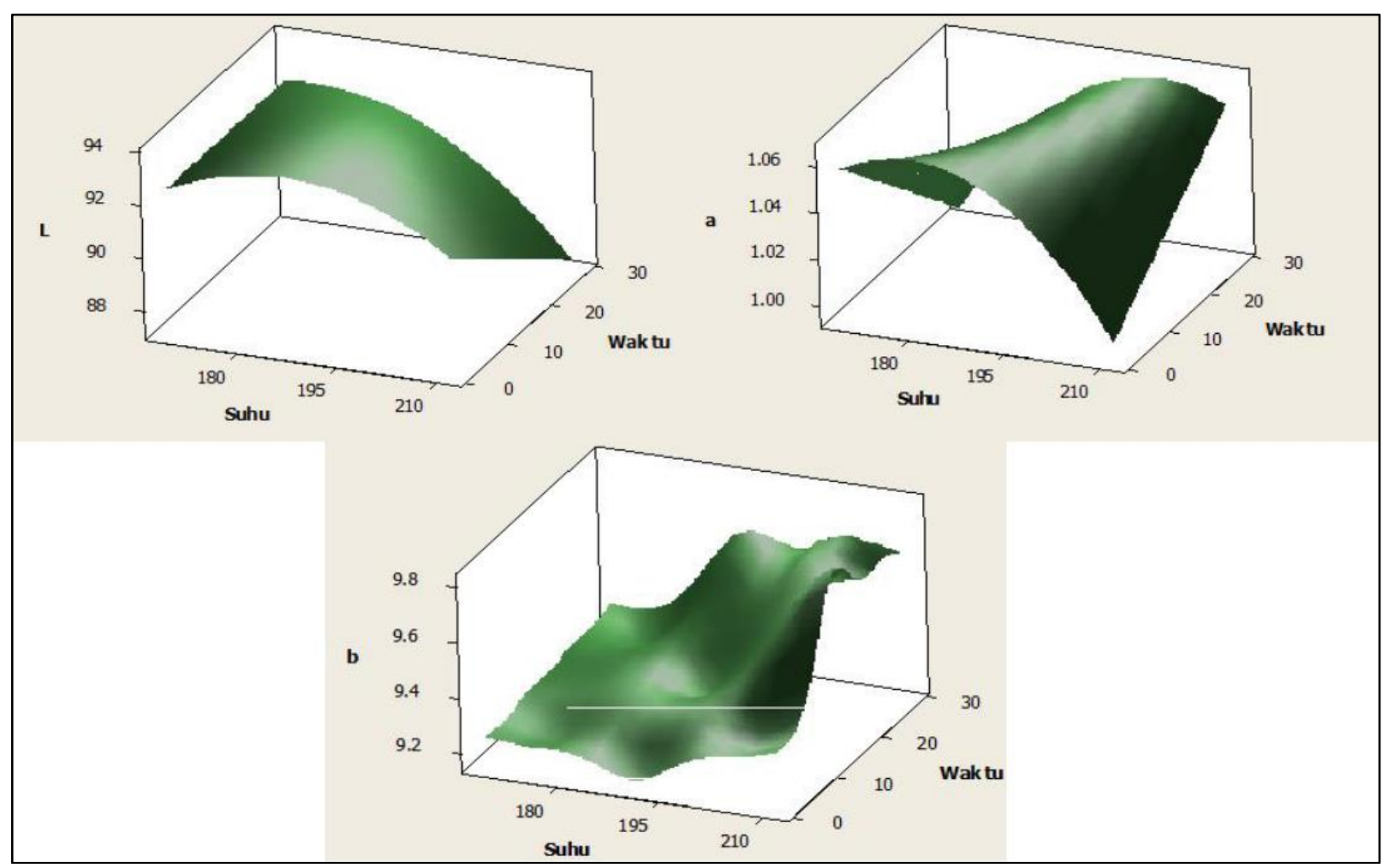

Gambar 1 Surface Plot untuk $\Delta E$ dengan kecepatan konveyor konstan

Gambar 1 menampilkan hasil ploting interaksi antara suhu dan waktu terhadap nilai Lab. Grafik menunjukan peningkatan suhu dan waktu akan meningkatkan nilai $b$ dan menurunkan nilai $L$. Dengan demikian peningkatan suhu dan waktu akan cenderung menjadi menguning dan warna lebih gelap. Peningkatan nilai $b$ berarti warna cenderung menguning, sedangkan penurunan nilai L menunjukan terjadi penurunan kecerahan warna.

\section{Optimasi Respon}

Optimasi respon untuk mencari nilai optimal pada ketiga respon $L a b$ tersebut digunakan fungsi desirability. Penentuan batasn nilai didasarkan pada ketentuan berbedaan warna tidak terdeteksi oleh pandangan mata jika memiliki selisih 0,3. Nilai target ditentukan dari pengukuran hasil sample panel standar dari vendor yang memiliki nila $L=92,04, a=1,04$ dan $b=9,24$. Batas atas dan batas bawah dihitung dengan cara menambahkan dan mengurangkan nilai standar dengan nilai penyimpangan. Pengaturan ketentuan optimasi yang dilakukan dengan menggunakan program Minitabl6 ditunjukkan pada Tabel 7 berikut ini:

Tabel 7 Batasan Optimasi Respon Menggunakan Fungsi Desirability

\begin{tabular}{|c|c|c|c|c|c|c|}
\hline Respon & Tujuan & Batas bawah & Target & Batas atas & $\omega$ & $I$ \\
\hline$L$ & Nominal terbaik & 91,74 & 92,04 & 95,04 & 1 & 1 \\
\hline$a$ & Nominal terbaik & 0,74 & 1,04 & 1,34 & 1 & 1 \\
\hline$b$ & Nominal terbaik & 8,94 & 9,24 & 9,54 & 1 & 1 \\
\hline
\end{tabular}

Hasil optimasi dengan menggunakan fungsi desirability yang dijalankan pada program Minitab 16 menghasilkan nilai optimal L sebesar 92,047, $a$ adalah 1,0484 dan $b 9,4662$ yang diperoleh pada saat nilai $D$ mencapai 0,18291. Gambar 3 menampilkan grafik optimasi fungsi desirability. Pengaturan faktor pada kondisi optimal adalah suhu oven sebesar 199,2 dan waktu curing 10,0003. Hal ini menunjukan bahwa seting optimal pada cat bubuk PW-01 adalah $199,2^{\circ} \mathrm{C}$ selama 10 menit mendekati nilai standard yaitu $200^{\circ} \mathrm{C}$ selama 10 menit. Pengujian warna yang dilakukan di laboratorium produsen cat bubuk PW-01 adalah $200^{\circ} \mathrm{C}$ selama 10 menit. 


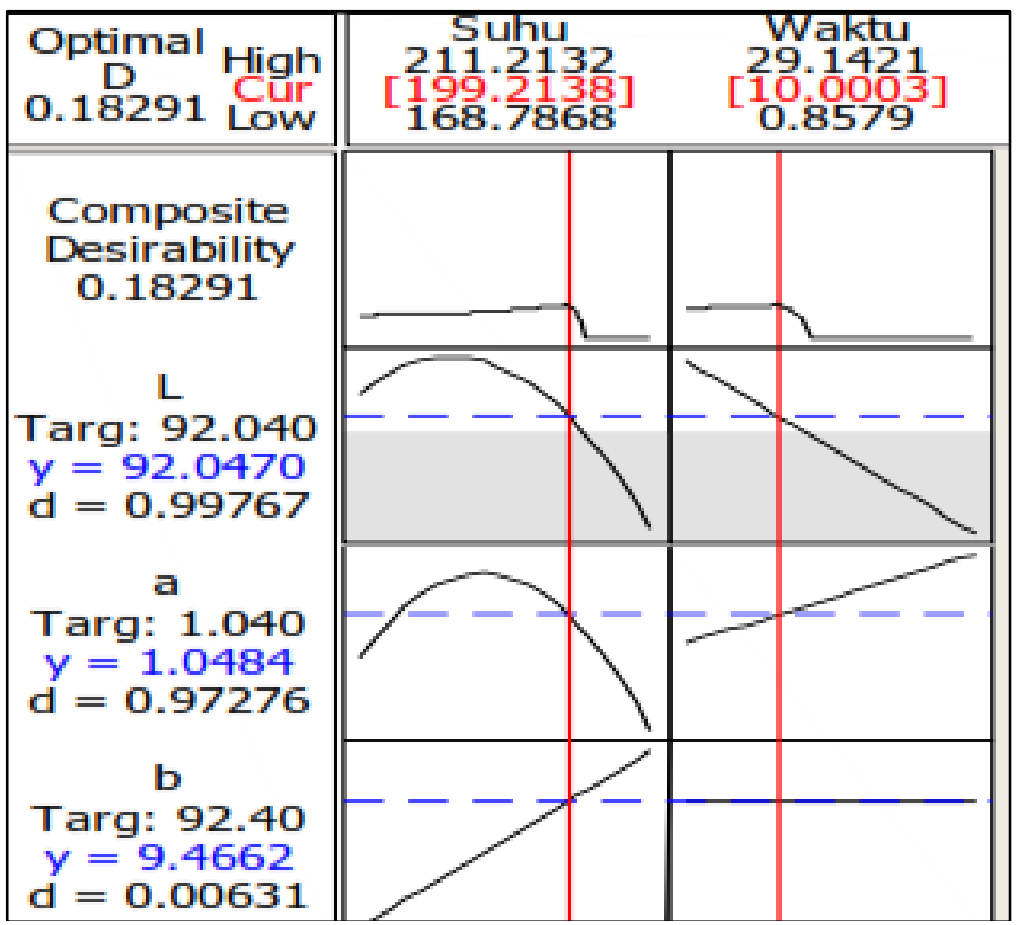

Gambar 2 Grafik optimasi fungsi desirability

\section{Kesimpulan}

Berdasarkan pemodelan, optimasi, perhitungan biaya dan pembahasan pada bab sebelumnya maka dapat diperoleh kesimpulan sebagai berikut:

1. Suhu dan waktu berpengaruh signifikan terhadap kecenderungan menguning dan kecerahan pada hasil pengecatan cat bubuk. Peningkatan suhu dan waktu akan menyebabkan hasil cat menguning dan menjadi lebih gelap.

2. Pemodelan pengaruh faktor suhu oven $\left(x_{1}\right)$ dan waktu pematangan dalam oven $\left(x_{2}\right)$ terhadap respon $L, a$, dan $b$ mengikuti persamaan orde dua berikut ini.

$Y_{L}=-27,9722+1,2988 x_{1}+0,5833 x_{2}-0,0035 x_{1}^{2}-0,0035 x_{1} x_{2}$

$Y_{\alpha}=-1,1064+0,0242 x_{1}-1,091 x_{2}-0,0001 x_{1}^{2}+0,0001 x_{1} x_{2}$

$Y_{b}=25,7463-1,761 x_{1}-0,1211 x_{2}+0,0005 x_{1}^{2}+0,0007 x_{1} x_{2}$

3. Optimasi dengan menggunakan fungsi desirability menghasilkan nilai $L$ sebesar $92,47, a$ sebesar 1,0484 , dan $b$ sebesar 9,4662 yang dilakukan pada setting suhu $199^{\circ} \mathrm{C}$ dengan waktu pemanasan 10 menit.

\section{Daftar Pustaka}

[1] D. K. Sahoo, A. N. Chari, and A. S. Reddy, "Optimization \& characterization of friction surfaced coatings of AA6063 aluminium alloy over AISI316 stainless steel substrate," Mater. Today Proc., vol. 23, pp. 565-572, 2020.

[2] S. . Kumar, "Comparation of Windows Made with Different Type of Material-A Case Study," Int. J. Civ. Struct. Eng., vol. 1, pp. 565-575, 2010.

[3] R. B. S. Majanasastra, "Analisis Sifat Mekanik dan Struktur Mikro Hasil Proses Hydroforming pada Material Tembaga ( Cu ) C84800 dan Aluminium Al 6063," J. Ilm. Tek. Mesin, vol. 4, no. 2, pp. 15-30, 2016. 
[4] Jalaluddin and T. Jamaluddin, "Pemanfaatan Kaolin Sebagai Bahan Baku Pembuatan Aluminimum Sulfat Dengan Metode Adsorps," J. Sist. Tek. Ind., vol. 6, no. 5, pp. 71-74, 2005.

[5] P. V. S. Sairam, G. S. Rao, M. V. D. N. S. Madhavi, K. Rayapareddy, and K. Hemalatha, "Computational studies of molecular interactions in the binary mixtures of ethyl lactate and nitro-, chloro- and bromo-benzenes," Mater. Today Proc., vol. 23, pp. 458-464, 2020.

[6] A. A. dan Suhariyanto, "Peningkatan Sifat Mekanik Paduan Aluminium A356.2 dengan Penambahan Manganese (Mn) dan Perlakuan Panas T6," J. Tek. Mesin, vol. 8, no. 2, pp. 64-68, 2006.

[7] E. Efthymiou, O. N. Cöcen, and S. R. Ermolli, "Sustainable aluminium systems," Sustainability, vol. 2, no. 9, pp. 3100-3109, 2010.

[8] H. W. Xian, N. A. C. Sidik, and R. Saidur, "Impact of different surfactants and ultrasonication time on the stability and thermophysical properties of hybrid nanofluids," Int. Commun. Heat Mass Transf., vol. 110, no. November 2019, 2020.

[9] M. Kartaman, M. H. Al Hasa, and A. Paid, "Pengaruh temperatur terhadap sifat bahan paduan alumunium fero nikel," J. Urania, vol. 19, no. 2, pp. 109-118, 2013.

[10] Wardoyo and Sumpena, "Pengaruh Variasi Temperatur Quenching pada Aluminium Paduan AlMgSi-Fe12\% terhadap Keausan," J. Engine Energi, Manufaktur, dan Mater., vol. 2, no. 1, p. $33,2018$.

[11] A. K. Chaitanya, D. K. Babu, and K. V. N. G. Kumar, "Experimental study on surface roughness by using abrasive jet machine," Mater. Today Proc., vol. 23, pp. 453-457, 2020.

[12] O. Nirmala, P. S. Reddy, and V. D. Reddy, "Synthesis of hexagonal YMnO3 nanocrystals, characterization and study of their dielectric properties," Mater. Today Proc., vol. 23, pp. 490494, 2020.

[13] S. B. Uyyala and S. Pathri, "Investigation of tensile strength on friction stir welded joints of dissimilar aluminum alloys," Mater. Today Proc., vol. 23, pp. 469-473, 2020.

[14] B. Surono and M. Nofri, "Perubahan Nilai Kekerasan dan Struktur Mikro Al-Mg-Si Akibat Variasi Temperatur Pemanasan," J. Ilm. Koleks. Perpust. UPN Veteran Jakarta, vol. 7, no. 2, pp. 135-140, 2011.

[15] P. E. Setyawan, Y. S. Irawan, and W. Suprapto, "Kekuatan Tarik dan Porositas Hasil Sambungan Las Gesek Aluminium 6061 dengan Berbagai Suhu Aging," J. Rekayasa Mesin Vol.5, vol. 5, no. 2, pp. 141-148, 2014.

[16] S. Fatemi, M. . Varkani, Z. Ranjbar, and S. Bastani, "Optimization of Water-Based RoadMarking Paint by Experimental Design, Mixture Method," Prog. Org. Coat., vol. 55, pp. 337-344, 2006.

[17] S. M. Mirabedini, S. S. Jamali, M. Hahghayegh, M. Sharifi, A. S. Mirabedini, and R. H. Nasab, "Application of Mixture Experimental Design to Optimize Formulation and Performance of Thermoplastic Road Markings," Prog. Org. Coat., vol. 75, pp. 549-559, 2012.

[18] Z. Bazrafshan and F. Ataeefard, M Nourmohammadian, "Modeling The Effect of Pigment and Processing Parameters in Polymeric Composite for Printing Ink Application Using The Response Surface Methodology," Prog. Org. Coat., vol. 82, no. 68-73, 2015.

[19] B. O. Sukram, "Optimasi Perbedaan Warna dan Kilap Cat bubuk Menggunakan Metode Permukaan Respon,” Semin. Manaajemen Teknol. XXIV, pp. A36-1-12, 2016. 
[20] Y. Xuan and Q. Li, "Heat transfer enhancement of nanofluids," Int. J. Heat Fluid Flow, vol. 21, no. 1, pp. 58-64, 2000.

[21] B. Orr, A. Akbarzadeh, M. Mochizuki, and R. Singh, "A review of car waste heat recovery systems utilising thermoelectric generators and heat pipes," Appl. Therm. Eng., vol. 101, pp. 490-495, 2016.

[22] D. . Montgomery, Design and Analysis of Experiments, 7th editio. New York: John Wiley \& Sons, Inc, 2009.

[23] J. Boeke, U. Knaack, and M. Hemmerling, "Superposition matrix for the assessment of performance-relevant adaptive façade functions," J. Facade Des. Eng., vol. 7, no. 2, pp. 1-20, 2019.

[24] N. Iriawan and S. P. Astuti, Mengolah Data Statistik dengan Mudah Menggunakan Minitab 14. Yogyakarta: Andi Publisher, 2006.

[25] C. F. J. Wu and M. Hamada, Experiments Planning, Analysis, and Parameter Design Optimization. New York: John Wiley \& Sons, Inc, 2000. 